\title{
Corporate social responsibility and firm performance in Thailand
}

\author{
Chutimant Boonnual \\ Wanchai Prasertsri \\ Faculty of Business Administration \\ Rajamangala University of Technology Thanyaburi, Thailand
}

Panarat Panmanee

School of Business, University of the Thai Chamber of Commerce, Thailand

\section{Keywords}

Corporate social responsibility, corporate governance, Thailand, public firms

\begin{abstract}
The purpose of this study was to investigate relationships between corporate social responsibility disclosure and firm performance in publicly-listed firms in Thailand using a stakeholder theory, proposed by R. Edward Freeman (1984). The theory identifies stakeholders in six groups: shareholders, customers, employees, suppliers, the local community and the natural environment. Data were collected based on the content analysis from annual reports published by the 394 companies in the Stock Exchange of Thailand 2014. Multiple regression analysis was used to identify the relationship between CSR and firm performance. The study found that all six group dimensions of CSR disclosure are positively related to return on assets (ROA), particularly disclosure in dimensions such as investors and customers. This study furthers understanding of CSR disclosure and its consequences.
\end{abstract}

Corresponding author: Chutimant Boonnual

Email address for corresponding author: chutimant_b@mail.rmutt.ac.th

First submission received: 23 rd March 2017

Revised submission received: 25th May 2017

Accepted: 28th June 2017

\section{Introduction}

The core focus of this research is corporate social responsibility ( or CSR). CSR is a modern business perspective and strategy based on the idea of stakeholder theory, which posits that the firm exists for the greater good of society rather than just its shareholders (Kotler \& Lee, 2011). Stakeholder theory was originally proposed and developed by Freeman (1984), and has been developed into a broader ethical position for firms. Freeman (1984) proposed that firms had an obligation to balance the needs of six groups of stakeholders, including shareholders, customers, employees, suppliers, the community, and the natural environment. This opposes the shareholder theory of the firm, proposed by Milton Friedman and others, which requires holds that the firm should only benefit its economic owners (shareholders) (Smith, 2003). However, the precise definition of CSR is widely contested in the literature, and different stakeholder groups may be identified. This research uses Freeman's (1984) original stakeholder framework as its analytical frame.

CSR can take many forms when actualized in firm strategy, including employer and supplier codes of conduct, community participation programs, philanthropic activity, cause-related marketing, and environmental impact assessment, and control of the firm's own activities (Kotler \& Lee, 2011). As an example, the coffee firm Starbucks is known for its CSR activities, which include Fair Trade participation (supplier protections), well building and water supply programs, and ethical treatment of employees (Kotler \& Lee, 2011). Regardless of the specific form, CSR is meant to be (and will be interpreted by customers as) a reflection of the firm's internal ethics and values. Thus, the most basic importance of CSR is that it demonstrates to consumers and potential consumers the 
value of the brand. Some studies have found that CSR can contribute to the bottom line, but this is not assured (Kotler \& Lee, 2011).

Thailand is one of the strongest countries for corporate governance, or ethical disclosure of firm practices and policies, in Asia (Robinett, 2013). Evidence suggests that Thai firms are actively and effectively using CSR strategies, although firms are not as aggressive about reporting CSR initiatives as in some other countries (Chapple \& Moon, 2005; Ratanajongkol, Davey, \& Low, 2006). CSR has also been shown to directly affect on Thai customers' perceptions of firms that use it, including increasing perceived service quality, trust in the firm, and brand effect (Poolthong \& Mandhachitara, 2009). These studies show that firms are using CSR and that consumers are responding.

This raises the question of what CSR can offer to the Thai economy more broadly. Studies have suggested that CSR can improve the profitability of firms, even in cases where it does not directly improve sales (Kapoor \& Sandhu, 2010). A systematic economic survey found that CSR has an effect on consumer markets, with firms demonstrating CSR generally having a stronger performance within these markets (Kitzmueller \& Shimshack, 2012). This survey also found that there was evidence that CSR induced innovation and encouraged labor market improvements. Given the dependence of Thailand on the export market, CSR may also have an effect on external consumer demand, particularly if it includes strong environmental sustainability measures (Kotler \& Lee, 2011). Some consumers do respond poorly to CSR and even avoid it, and the shareholder theory of the firm holds that it is inappropriate to devote resources to CSR since it does not directly benefit shareholders (Kotler \& Lee, 2011). On the balance, however, evidence suggests that CSR can improve performance on at the firm level, through improved processes, innovation, and customer response. When applied across an economy, it could substantially improve economic performance throughout industry industrial sectors.

\section{Literature Review and Conceptual Framework}

A few studies demonstrate the generally positive relationship between CSR and firm performance. A study in India used the six-dimensional stakeholder perspective to examine CSR impact on firms in India (Mishra \& Suar, 2010). That study collected data about CSR and firm performance from 150 companies. The results showed that publicly-listed firms were more likely to use both CSR and report better financial performance than private firms. Additionally, CSR acceptance within the firm is associated with improved financial performance. Thus, the preliminary results of this that study do support a positive relationship between CSR and firm financial performance. A literature review on CSR shows that this effect can be generalized; a large number of studies have found that CSR generates indirect and direct positive effects on the firm's financial performance (Carroll \& Shabana, 2010). These effects have been attributed to a variety of factors, including improved employee commitment and performance, better supplier relationships, less waste, and improved customer perceptions and loyalty (Carroll \& Shabana, 2010). This Study also points that the benefits such as improved reputation and stock performance related to CSR. Thus, generally speaking, the research supports a positive relationship between CSR and firm performance.

A very recent study suggests that not all CSR has equal effects on the firm (Jayachandran, Kalaignanam, \& Eilert, 2013). Jayachandran et al. (2013) identified aspects of CSR relating to the product and the environment, and compared these aspects of CSR on the firm's financial performance. They found that, while both types of CSR did affect financial performance, the product social performance aspects (related more to suppliers, employees, and customers) had a much stronger effect than the environmental performance aspects. Thus, firms may see different effects from CSR depending on their CSR focus, as well as the appropriateness of their activities to the preferences of their customer base. A study in the oil industry also founds that the effect of CSR on firm performance may be moderated by other factors (Lee, Seo, \& Sharma, 2013). Lee, et al. (2013) studied the American airline industry to determine the effect of operational and non-operational CSR 
activities. They found that, in general, these activities had a positive effect on financial performance. However, oil prices were a negative moderating factor in the impact of operational activities on firm performance. Thus, it is too simplistic to say that CSR will definitely improve firm performance, since this could depend on a number of factors outside the direct control of the firm.

The literature on CSR's impact on the firm is not uniformly in agreement, as the studies discussed in brief above demonstrate. In particular, it appears that the relationship of CSR to firm performance depends on the CSR activity and industry conditions. Additionally, there has been relatively little research on the impact of CSR on Thai firms in recent years, although, as previously noted, Thai firms are known to use CSR and Thai consumers respond to it (Poolthong \& Mandhachitara, 2009) (Ratanajongkol, Davey, \& Low, 2006). Thus, there is a clear research gap and this research will fills is determining how CSR policies have affected Thai firm performance within the most recent time period (2014), which corresponds with increasing economic growth and globalization.

Overall, the empirical evidence strongly supports the theoretical positive relationship between CSR and firm performance. However, there are aspects of the firm and the CSR program that can complicate this relationship.

\subsection{CSR Stakeholder Analysis}

CSR is inherently related to stakeholder theory, because stakeholder theory provides the foundation for CSR activities within the firm (Kakabadse, et al., 2005). Simply, without stakeholder theory, there is no justification for the firm to devote energy to fulfilling its ethical or philanthropic responsibilities. Thus, understanding the role of stakeholder analysis in CSR is key to understanding the concept of CSR itself. In this section, a definition of stakeholder analysis in CSR is presented. Next, the roles of various stakeholders in CSR are examined. Finally, approaches to the measurement of stakeholder perceptions of CSR activities are critiqued. In this discussion, six stakeholders (employees, suppliers, customers, owners/ (shareholders), the community, and the environment) are examined. This leaves out management, which was identified as a stakeholder group by Freeman (1984). However, the management perspective is difficult to consider in this case because of the management role in setting CSR policy.

The overall problem of measurement of CSR perceptions is not resolved, and it remains an active area for further research (Aguinis \& Glavas, 2012). The development of such instruments is hampered because the underlying relationships between firms and stakeholder groups are not well understood. However, the research suggests that measuring stakeholder perceptions toward CSR is likely to be done most effectively using a survey, though external information (such as actions) could also be used. This is actually at odds with the process of stakeholder analysis, which is primarily qualitative (Harrison \& Wicks, 2010). However, it also is a way to collect information about perceptions in a more standardized fashion.

\subsection{Hypothesis Development}

In order to examine the current research problem, two hypotheses have been proposed based on the existing literature and known findings. However, because some of the research is not as strong as it might be useful, directionality of relationships has not been addressed.

The first hypothesis addresses the relationship between CSR, stakeholder perspectives, and firm performance. The research clearly supports a relationship between CSR activities and firm financial performance, and, in most cases, this relationship is found to be generally positive (Carroll \& Shambana, 2010; Golicic \& Smith, 2013; Kotler \& Lee, 2011; Mishra \& Saur, 2010; Qu, 2009; Tang, et al., 2011). This is distinct from any non-financial performance measures, which are not considered in the current study. There are some subtleties, such as firm and industry structure (Hull \& Rothenberg, 2008); CSR program orientation (Jayachandran, et al., 2013); and time-frame of the program (Lin, et al., 2009; Nelling \& Webb, 2009; Tang, et al., 2011). Manipulative or dishonest use of CSR can also 
negatively impact firm performance (Fooks, et al., 2013; Janney \& Gove, 2011). Overall, however, the empirical evidence suggests that good-faith CSR programs have a positive impact on firm financial performance.

The second aspect of this hypothesis is the difference in stakeholder perspectives. Stakeholder perspectives are inherently related to types or streams of CSR programs used by firms and these programs have a different impact on firm performance (Inoue \& Lee, 2011). Thus, it is not just the existence of CSR programs that influences the firm's outcomes, but also how its stakeholders perceive it. A few comparative studies have identified differences in stakeholder group perceptions and outcomes on the firm's performance (Mahon \& Wartick, 2012; Mishra \& Saur, 2010). This evidence is not as strong as it might be, offering an opportunity for comparative research. However, a number of studies of individual perspectives have identified differential impacts of stakeholder groups on firm performance and conditions under which it occurs. For example, the impact customer perspective of CSR on consumer-facing firms such as retail firms is potentially very strong, but is not effective unless consumer awareness is high (Servaes\& Tamayo, 2013). Similarly, support for some perspectives may come from unexpected quarters; for example, evidence suggests that institutional investors (nominally representing the shareholder perspective) also improve environmental protections (thus, also representing the environment's perspective) (Walls, et al., 2012). Thus, there is substantial evidence that stakeholder perspectives have different effects on CSR. Based on this evidence, the first hypothesis is posed:

There is a positive relationship between CSR in stakeholder perspectives (community, supplier, employee, shareholder, customer and environment) and firm performance.

\section{Research Design}

The research design relies on secondary published information, specifically annual reports. Quantitative data will were used to model firm performance, specifically data from the firm's annual reports. However, there is no set quantitative metric that can be used to measure CSR. Instead, qualitative data wwere assessed and systematically condensed into a quantitative score or metric for CSR utilization. This approach can be described as a systematic approach to qualitative data. This index-building approach is commonly used to measure business outcomes where there is no specific single quantitative metric that could be used (Zikmund, Babin, \&Carr, 2012). It is somewhat vulnerable to bias, given that the researcher will ultimately select the data for assessment, but this can be avoided by using a systematic and outlined approach to data collection and analysis (Zikmund, Babin, \& Carr, 2012). This was preferable to as in some other studies relying on consumer or manager perceptions of CSR as a proxy for firm CSR activities, as applied in some other studies.

\subsection{Independent Variables}

There are six independent variables in the study. Each of these relates to one of the six dimensions of stakeholder theory as indicated by Freeman (1984). However, there is no direct quantitative indication of CSR performance in these areas. This means that an indexing system had to be found. However, the researchers preferred not to construct an indexing system, because of concerns about validity and reliability of a new scale (Zikmund, Babin, \&Carr, 2012).

The recent research by Kapoor and Sandhu (2010), which studied CSR and firm performance in India, providesd a solution for transforming qualitative observations of CSR activities to quantitative measurements that could be used for statistical analysis. The authors constructed a 44item index of CSR items, each of which reflects an aspect of one of the six stakeholder categories (Kapoor \& Sandhu, 2010), and plus moreadded 26 -items that relate to G4 from GRI. Disclosure of items is assigned a value of 1 , and non-disclosure a value of 0 . On completion of content analysis, there is an index score generated from each of the items that related to the appropriate stakeholder category. The index score represents the percentage of the total number of items in the category that were disclosed by the firm. This does have flaws, particularly in that it does not reflect the firm's 
view of the relative importance of a particular effort (Kapoor \& Sandhu, 2010). However, it does provide a standardized representation of firm CSR activities, which is particularly useful. The items and scoring measures have been used as presented by the authors, in order to avoid introducing unreliable measures.

\subsection{Data Collection}

The population of interest in this research is Thai firms. The sample that was publicly-listed firms on the Stock Exchange of Thailand (SET) in 2014. The main sources of data were SETSMART, or the SET Market Analysis and Reporting Tool. This database includes annual financial reports and performance figures for all firms listed on the Stock Exchange of Thailand (SET).

The annual reports listed in SETSMART were also used to collect information about the CSR perspectives, as described above. However, test sampling has shown that annual reports do not always include comprehensive information about CSR activities. In order to fill this gap, further research was done using the firm's own website and corporate social and sustainability reports. This holistic approach allows the broadest possible capture of information about CSR activities and enables accurate CSR scoring using the method outlined above. All sources were listed and disclosed.

\subsection{Data Analysis}

There are two data analysis techniques used in this study. The first technique is factor analysis, while the second is multiple regression analysis. Factor analysis is used to provide a single consolidated index variable to be used as an independent variable, while multiple regression analysis is used to test the relationship between dependent and independent variables.

The first step in the analysis will be is to consolidate the six independent variables into a single representative CSR index. One of the problems with the six independent variables is that they provide a divergent picture of the CSR activities when applied to multiple firms. Firms do not tend to pursue the same CSR activities, because of differences in operations, ethics, and stakeholder impacts (Kotler \& Lee, 2011). Thus, to simply compare firms based on one dimension of the stakeholder theory is likely to not provide a fair comparison. In order to condense the six perspectives into a single composite index of CSR disclosure that will fairly represents all firms, factor analysis is used. Factor analysis is an analytical method that is used to uncover latent variables or factors from a data set (Fabrigar\& Wegener, 2012). In essence, factor analysis identifies factors (or unobserved variables) based on relationships in variation among a set of observed variables.

Multiple regression analysis is the tool used to identify the relationship between CSR and firm performance. Regression analysis describes a relationship between the independent variable (styled X) and dependent variable (styled Y) (Crown, 1998). This relationship can be recognized as the line-slope equation. The line-slope equation represents the co-variation of the two variables (Crown, 1998). Regression equations can beare used to understand the strength of a relationship between two variables using the R2 value, and can also beare used to predict the dependent variable based on the independent variables. Multiple regression analysis includes more than one $X$ variable.

\section{Results}

\section{Table1: Factor Analysis}

KMO and Bartlett's Test

\begin{tabular}{|c|c|c|}
\hline $\begin{array}{l}\text { Kaiser-Meyer-Ol } \\
\text { Adequacy. } \\
\text { Bartlett's Test of } \\
\text { Sphericity }\end{array}$ & $\begin{array}{l}\text { re of Sampling } \\
\text { Approx. Chi-Square } \\
\text { df } \\
\text { Sig. }\end{array}$ & $\begin{array}{r}.844 \\
1279.211 \\
15 \\
.000\end{array}$ \\
\hline
\end{tabular}


Table 1 show that KMO was equal .844 and were significant at $P$-value $<0.000$. Factor Analysis result providedfound that all six groups of CSR disclosure variables (: employee, employee, customer, environment, communication, investor and supplier) had significant relationships. Thus, it is appropriate for this study to can take apply fFactor aAnalysis technique.

In the regression model the ROA is regressed on the score in six groups of CSR disclosure variables, as per the following equation as follow:

ROA $=\beta_{0}+\beta_{1}$ employee $+\beta_{2}$ customer $+\beta_{3}$ environment $+\beta_{4}$ communication $+\beta_{5}$ investor $+\beta_{6}$ supplier $+e$

Results of the descriptive statistics analysis provided are shown in Table 2 that present minimum, maximum, mead and Standard deviation of all variables. The Ccorrelation matrix is shown in tTable 3 is use for initial analysis, followed by then multiple regression analysis to test the $\mathrm{s}$ for enhancement hypothesis test from the data.

Table 2: Descriptive Statistics

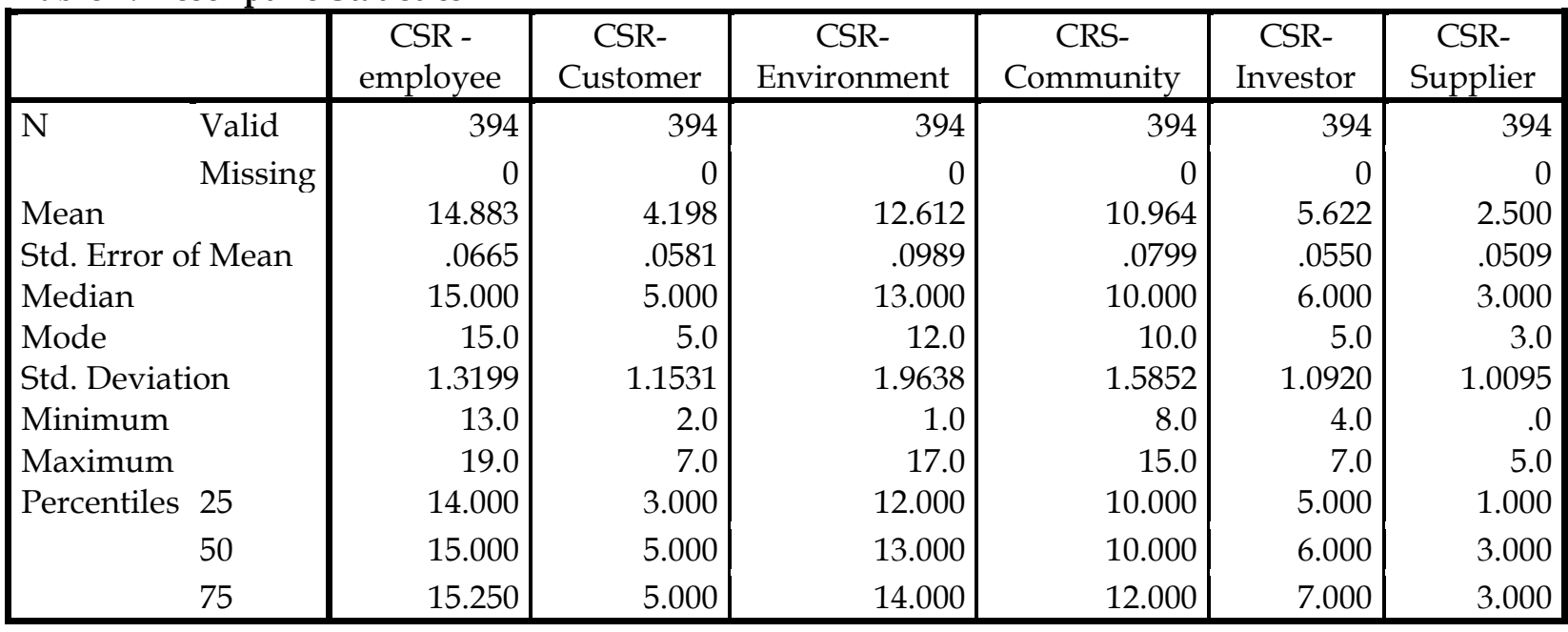

Table3:Correlations

\begin{tabular}{|c|c|c|c|c|c|c|c|c|}
\hline & ROA & Employee & Customer & \begin{tabular}{|l|} 
Environment \\
\end{tabular} & Community & Investor & Supplier \\
\hline \multirow{7}{*}{$\begin{array}{l}\text { Pearson } \\
\text { Correlation }\end{array}$} & ROA & 1.000 & .400 & .404 & .325 & .319 & .411 & .340 \\
\hline & employee & .400 & 1.000 & .704 & .525 & .570 & .640 & .735 \\
\hline & Customer & .404 & .704 & 1.000 & .403 & .362 & .615 & .750 \\
\hline & Environment & .325 & .525 & .403 & 1.000 & .610 & .438 & .397 \\
\hline & Community & .319 & .570 & .362 & .610 & 1.000 & .435 & .391 \\
\hline & Inve & .411 & .640 & .615 & .438 & .435 & 1.000 & .557 \\
\hline & Supplier & .340 & .735 & .750 & .397 & .391 & .557 & 1.000 \\
\hline \multirow{7}{*}{$\begin{array}{l}\text { Sig. (1- } \\
\text { tailed) }\end{array}$} & ROA & & .000 & .000 & .000 & .000 & .000 & .000 \\
\hline & Employee & .000 & & .000 & .000 & .000 & .000 & .000 \\
\hline & Customer & .000 & .000 & & .000 & .000 & .000 & .000 \\
\hline & Environment & .000 & .000 & .000 & & .000 & .000 & .000 \\
\hline & Community & .000 & .000 & .000 & .000 & & .000 & .000 \\
\hline & Investor & .000 & .000 & .000 & .000 & .000 & & .000 \\
\hline & Supplier & .000 & .000 & .000 & .000 & .000 & .000 & \\
\hline
\end{tabular}


Table4: Model Summary

\begin{tabular}{|c|c|c|c|c|c|c|c|c|c|c|}
\hline \multirow[b]{2}{*}{ Model } & \multirow[b]{2}{*}{$\mathrm{R}$} & \multirow[b]{2}{*}{$\begin{array}{c}\mathrm{R} \\
\text { Square }\end{array}$} & \multirow[b]{2}{*}{$\begin{array}{l}\text { Adjusted R } \\
\text { Square }\end{array}$} & \multirow[b]{2}{*}{$\begin{array}{l}\text { Std. Error of } \\
\text { the Estimate }\end{array}$} & \multicolumn{5}{|c|}{ Change Statistics } & \multirow[b]{2}{*}{$\begin{array}{l}\text { Durbin- } \\
\text { Watson }\end{array}$} \\
\hline & & & & & $\begin{array}{l}\text { R Square } \\
\text { Change }\end{array}$ & $\begin{array}{c}\mathrm{F} \\
\text { Change }\end{array}$ & df1 & $\mathrm{df} 2$ & $\begin{array}{c}\text { Sig. F } \\
\text { Change }\end{array}$ & \\
\hline 1 & $.479^{a}$ & .229 & .217 & 8.29273 & .229 & 19.188 & 6 & 387 & .000 & 1.851 \\
\hline
\end{tabular}

a. Predictors: (Constant), CSR- Supplier, CRS- Community, CSR- Investor, CSR- Environment, CSR-

Customer, CSR - employee

b. Dependent Variable: ROA

Table 5 ANOVAnova Analysis

\begin{tabular}{|ll|r|r|r|r|r|}
\hline \multicolumn{2}{|l|}{ Model } & \multicolumn{1}{|c|}{$\begin{array}{c}\text { Sum of } \\
\text { Squares }\end{array}$} & df & Mean Square & F & \multicolumn{1}{c|}{ Sig. } \\
\hline 1 & Regression & 7917.370 & 6 & 1319.562 & 19.188 & $.000^{\mathrm{b}}$ \\
& Residual & 26613.723 & 387 & 68.769 & & \\
& Total & 34531.093 & 393 & & & \\
\hline
\end{tabular}

a. Dependent Variable: ROA

b. Predictors: (Constant), CSR-Supplier, CRS- Community, CSR- Investor, CSR-

Environment, CSR- Customer, CSR - employee

Tables 4 and 5 provide a regression analysis result thatwith statisticalcally significancet at Pvalue $<0.000$. The, F-test was equal to 19.188 and Durbin -Watson was equal to 1.851. That means that CSR disclosure across all six groups has an effected on ROA. Therefore, this study accepted hypothesis.

\section{Discussion and Summary}

This study examines the nature and measure of corporate social responsibility CSR (CSR) disclosure in listed firms in Thailand in 2014. It investigateds the relationship between CSR and firm performance. The result was significant in relation to the purpose. There is mixed evidence for the relationship of CSR and firm financial performance (as measured by ROA). In theory, the firm could recognize direct economic benefits like such as increased sales due to improved corporate reputation and consumer trust, and indirect effects like such as improved efficiency and employee commitment (Kotler and Lee, 2011). Several studies have also had empirical findings that supported a positive relationship of CSR and either ROA or ROE (Mishra and Suar, 2010; Golicic and Smith, 2013; Qu, 2009; Tang, Hull, and Rothenberg, 2011). These findings are not entirely consistent; an extensive review revealed that CSR is a complex construct and different CSR aspects had different effects on financial performance (Carroll and Shambana, 2010). However, there evidence strongly points to a positive relationship between CSR disclosure and related activities and financial performance. Studies of ROE (Mishra and Suar, 2010; Golicic and Smith, 2013; Qu, 2009; Tang, Hull, and Rothenberg, 2011) which, matched with the results from this study. Thus, the research hypothesies is accepted and support.

There are some significant limitations to the methods that are chosen in this research. The first issue is that the research only included publicly-listed firms. This wais required because of differences in financial information availability and CSR disclosure between publicly-listed and privately-owned firms in Thailand. However, it does mean that factors such as public and regulatory pressure may have an undetected influence on the outcomes of the study. The second limitation is that the time period of the study is relatively recent. This means that historical trends are not reflected in the findings. Given the redesign of Thailand's markets and financial structures following the 1997 financial crisis, this is not necessarily a negative factor, but it does pose a limitation. The use of SET as a data source also imposes a geographic and ownership limitation. In particular, the firms that are listed on SET are mainly domestic Thai firms, and most ownership of Thai stocks is also domestic. This means that the results of the study is directly linked to Thailand, though the findings 
might be applied in an analytical sense to other markets. A final limitation is that assessment of CSR scores is by its nature somewhat subjective. Although the researchers used a systematic approach, there is still an element of judgment that could not be eliminated, and that may introduce bias. The researchers were aware of this and will workstrived to avoid any such bias making its way into the analysis.

Future research could include a comparison of a cross-sectional study of Thailand and other members of the ASEAN Economic Community. To deepen our understanding, future research could compare the study of developed countries and developing countries in an attempts to understand the nature and extent of CSR disclosure and its relationship to financial performance. It is important to understand the extent of CSR components in other countries. Moreover, future research could apply a longitudinal method by using more years' of data and a larger sample size. This would increase the reliability of the results. Finally, our findings found that the disclosure of CSR information pays off has potentially far-reaching implications for corporate decision making and strategic management. In particular, companies may find it worthwhile to devote sufficient resources to developing and implementing their CSR strategy. From a broader perspective, this insight suggests an important, and perhaps unique, feature of CSR for stakeholder benefit-employees, customers, shareholders, environment, community and society-at-large. Therefore, the relevant authorities should be encouraged to do encourage more and CSR activities to cover all stakeholder groups.

\section{References}

Carroll, A. B., \& Shambana, K. M. (2010). The business case for corporate social responsibility: A reveiw of concepts, research and practice. International Journal of Management Reviews, 85-105.

Chapple, W., \& Moon, J. (2005). Corporate social responsibility (CSR) in Asia: A seven country study of CSR web site reporting. Business and Society, 44(4), 415-441.

Crown, W. H. (1998). Statistical models for the social and behavioral sciences. New York: Greenwood.

Fabrigar, L. R., \& Wegener, D. T. (2012). Exploratory factor analysis. Oxford: Oxford University Press.

Fooks, G., Gilmore, A., Collin, J., Holden, C., \& Lee, K. (2013). The limits of corporate social responsibility: Techniques of neutralization, stakeholder management, and political CSR. Journal of Business Ethics, 112, 283-299.

Freeman, R. E. (1984). Strategic management: A stakeholder approach. Boston, MA: Pitman.

Golicic, S. L., \& Smith, C. D. (2013). A meta-analysis of environmentally sustainable supply chain management practices and firm performance. Journal of of Supply Chain Management, 49(2), 7895.

Harrison, J. S., \& Wicks, A. C. (2010). Stakeholder theory: The state of the art. Cambridge, UK: Cambridge University Press.

Hull, C. E., \& Rothenberg, S. (2008). Firm performance: The interactions of corporate social performance with innovation and industry differentiation. Strategic Management Journal, 29, 781-789.

Inoue, Y., \& Lee, S. (2011). Effects of different dimensions of corporate social responsibility on corporate financial performance in tourism-related industries . Tourism Management, 32(4), 790804.

Janney, J. J., \& Gove, S. (2011). Reputation and corporate social responsibility aberrations, trends and hypocrisy: Reactions to firm choices in the stock option dating scandal. Journal of Management Studies, 48(7), 1562-1585.

Jayachandran, S., Kalaignanam, K., \& Eilert, M. (2013). Product and environmental social performance: Varying effect on firm performance . Strategic Management Journal, 34(10), 12551264. 
Kapoor, S., \& Sandhu, H. S. (2010). Does it pay to be socially responsible? An empirical examination of impact of corporate social responsibility on financial performance. Global Business Review, 11(2), 185-208.

Kitzmueller, M., \& Shimshack, J. (2012). Economic perspectives on corporate social responsibility. Journal of Economic Literature, 50(1), 51-84.

Kotler, P., \& Lee, N. (2011). Corporate social responsibility: Doing the most good for your company and your cause. Hoboken, NJ: John Wiley and Sons.

Lee, S., Seo, K., \& Sharma, A. (2013). Corporate social responsibility and firm performance in the airline industry: The moderating role of oil prices . Tourism Management, 38, 20-30.

Lin, C., Yang, H., \& Liou, D. (2009). The impact of corporate social responsibility on financial performance: Evidence from business in Taiwan. Technology in Society, 31, 56-63.

Mahon, J., \& Wartick, S. L. (2012). Corporate social performance profiling: using multiple stakeholder perceptions to assess a corporate reputation. Journal of Public affairs, 12(1), 12-28.

Mishra, S., \& Suar, D. (2010). Does corporate social responsibility influence firm performance of Indian companies? Journal of Business Ethics, 95, 571-601.

Nelling, E., \& Webb, E. (2009). Corporate social responsibility and financial performance: The "virtuous circle" revisited. Review of Quantitative Financial Accounting, 32, 197-209.

Poolthong, Y., \& Mandhachitara, R. (2009). Customer expectations of CSR, perceived service quality and brand effect in Thai retail banking. International Journal of Bank Marketing, 27(6), 408-427.

$\mathrm{Qu}, \mathrm{R}$. (2009). The impact of market orientation and corporate social responsibility on firm performance: Evidence from China . Asia Pacific Journal of Marketing and Logistics, 21(4), 570582.

Ratanajongkol, S., Davey, H., \& Low, M. (2006). Corporate social reporting in Thailand: The news is all good and increasing. Qualitative Research in Accounting and Management, 3(1), 67-83.

Robinett, D. (2013, May 14). Corporate governance reforms pay dividends in Thailand. Retrieved from World Bank: http://blogs.worldbank.org/psd/corporate-governance-reforms-pay-dividendsthailand

Servaes, H., \& Tamayo, A. (2013). The impact of corporate social responsibility on firm value: The role of customer awareness. Management Science, 59(5), 1045-1061.

SETSMART. (2013). SET Marekt Analysis and Reporting Tool. Retrieved from

http:/ / www.setsmart.com/

Tang, Z., Hull, C., \& Rothenberg, S. (2011). How corporate social responsibility is pursued affects firm financial performance. Academy of management Proceedings, Meeting abstract supplement, 1-6.

Walls, J. L., Berrone, P., \& Phan, P. H. (2012). Corporate governance and environmental performance: Is there really a link? Strategic Management Journal, 33(8), 885-913.

Zikmund, W. G., Babin, J. C., \& Carr, M. G. (2012). Business research methods (9th ed.). Mason, OH: Cengage Learning. 